University of Nebraska - Lincoln

DigitalCommons@University of Nebraska - Lincoln

$4-2020$

\title{
A New Genus and Two New Species of Unarmed Hymenolepidid Cestodes (Cestoda: Hymenolepididae) from Geomyid Rodents in Mexico and Costa Rica
}

\author{
Scott Lyell Gardner \\ University of Nebraska - Lincoln, slg@unl.edu \\ Altangerel Tsogtsaikhan Dursahinhan \\ University of Nebraska - Lincoln, stylodipusats@gmail.com \\ Mariel Campbell \\ University of New Mexico, campbell@carachupa.org \\ S. Elizabeth Rácz \\ University of Nebraska - Lincoln, racz.eliz@gmail.com
}

Follow this and additional works at: https://digitalcommons.unl.edu/slg

Part of the Biodiversity Commons, Biology Commons, Ecology and Evolutionary Biology Commons, and the Parasitology Commons

Gardner, Scott Lyell; Dursahinhan, Altangerel Tsogtsaikhan; Campbell, Mariel; and Rácz, S. Elizabeth, "A New Genus and Two New Species of Unarmed Hymenolepidid Cestodes (Cestoda: Hymenolepididae) from Geomyid Rodents in Mexico and Costa Rica" (2020). Scott Gardner Publications \& Papers. 16. https://digitalcommons.unl.edu/slg/16

This Article is brought to you for free and open access by the Parasitology, Harold W. Manter Laboratory of at DigitalCommons@University of Nebraska - Lincoln. It has been accepted for inclusion in Scott Gardner Publications \& Papers by an authorized administrator of DigitalCommons@University of Nebraska - Lincoln. 


\title{
A new genus and two new species of unarmed hymenolepidid cestodes (Cestoda: Hymenolepididae) from geomyid rodents in Mexico and Costa Rica
}

\author{
SCOTT L. GARDNER ${ }^{1}$, ALTANGEREL T. DURSAHINHAN ${ }^{1}$, MARIEL L. CAMPBELL ${ }^{2} \&$ S. ELIZABETH \\ RÁCZ ${ }^{1}$ \\ ${ }^{1}$ Harold W. Manter Laboratory of Parasitology, University of Nebraska State Museum, University of Nebraska-Lincoln, Nebraska \\ 68588-0514,U.S.A.87131; ”"slg@unl.edu ○https://orcid.org/0000-0003-3133-740X; stylodipusats@gmail.com; racz.eliz@gmail. \\ com \\ ${ }^{2}$ Museum of Southwestern Biology, Department of Biology, University of New Mexico, Albuquerque, New Mexico; \\ carachupa.org
}

\begin{abstract}
Two new cestodes of the family Hymenolepididae are described from two species of rodents of the family Geomyidae collected in Mexico and Costa Rica. One new species of Hymenolepis is described from Cratogeomys planiceps Merriam 1895 from near Toluca, Mexico and another that we allocate to a new genus is described from Heterogeomys heterodus (Peters, 1865) from near Irazú Volcano, Costa Rica. Hymenolepis s. str. includes those Hymenolepididae with an apical organ, with no hooks on suckers or apical organ, and three testes. Hobergia irazuensis n. gen., n. sp. includes a hymenolepidid with an apical organ, unarmed scolex, small pockets termed foveolae, in which the suckers completely retract, and extremely bi-lobed ovary. Multivariate morphometric analysis showed good separation of these species from all other hymenolepidids possessing an apical organ and lacking a well developed rostellum and rostellar hooks in the Nearctic and Neotropical regions.
\end{abstract}

Key words: bilobed ovary, DAMA Protocol, discriminant analysis, Hobergia n. gen., Hobergia irazuensis n. gen., n. sp., Hymenolepididae, Hymenolepis cratogeomyos, new genus, new species, morphology

\section{Introduction}

As natural ecological systems on the earth continue to be rapidly obliterated by human activities it is imperative for scientists with knowledge of field biology to report in the scientific literature the results of field-based surveys based on specimens that were collected and deposited in recognized museums, thus establishing a record of the existence of species before they are completely annihilated (Brooks et al., 2014; Ceballos et al., 2017). Following, we provide descriptions of two new species of cestodes of the family Hymenolepididae recovered from pocket gophers (Rodentia: Geomyidae) collected from relatively high-altitude habitats in both Mexico and Costa Rica of the southern Nearctic and the northern Neotropical regions, respectively. To enable a more complete understanding of the hymenolepidid cestode fauna of pocket gophers, we start this paper by providing a basic introduction to these mammals.

Pocket gophers of the family Geomyidae Bonaparte, 1845 are subterranean rodents that have an extensive geographic and ecological range in the Nearctic and northern Neotropical regions with species representing several genera occupying suitable habitat in mostly the western and far southeastern North America, south through central America into the northern part of South America (Alberico 1990; Hall 1981; Solari 2013).

At the current time, about 40 species of pocket gophers are recognized with these having been allocated to six genera divided among two tribes including: The tribe Geomyini with Cratogeomys Merriam 1895, Geomys Rafinesque 1817, Heterogeomys Merriam 1895, Pappogeomys Merriam 1895, and Zygogeomys Merriam 1895, and the Tribe Thomomyini, includes only the speciose genus Thomomys Wied-Neuwied 1839 (see: Russell 1968; Wilson \& Reeder 2005; Spradling et al. 2016).

Extant species of Thomomys are known only from the western part of the Nearctic but fossils that can be as- 
signed to species included in this genus have been reported from sedimentary deposits as early as Pliocene time on the east coast of North America with records of extinct species of this genus ranging from the states of Maryland to Florida in the USA (Simpson 1928; Kurtén \& Anderson 1980; Wilkins 1985).

Published records derived from collections of parasites from Geomyidae in the Nearctic show that cestodes including species of the genus Hymenolepis Weinland, 1858 are common parasites of these rodents (Douthitt 1915; English 1932; Rankin 1945; Burnham 1953; Voge 1955; Frandsen \& Grundmann 1961; Gardner 1985; Gardner \& Schmidt 1988; Gardner et al. 2014). A review of this literature shows definitively that the Geomyidae have a specific and diverse helminth fauna especially relative to their hymenolepidid cestodes (Gardner \& Schmidt 1988; Makarikov et al., 2012; Gardner et al. 2014) but understanding the faunal structure and historical ecology of helminth parasitism in the geomyids in the Nearctic is still developing (Douthitt, 1915; English, 1932; Brooks \& McLennan, 1993; Bartel \& Gardner, 2000) and is still nascent in the northern Neotropical Region.

Up to the present time, investigations of tapeworms of the genus Hymenolepis from pocket gophers have mostly focussed on species of these mammals occurring in the western and central Nearctic region (Table 1) (Gardner \& Schmidt 1988) and little information is available relative to the helminth fauna of the Geomyidae from south of the United States/Mexico border; in fact, before the current work, no hymenolepidids from geomyid rodents had been reported in the primary literature from Mexico, Central America, or northern South America.

TABLE 1. List of reports of species of the family Hymenolepididae from Geomyidae in the Nearctic and northern Neotropical regions.

\begin{tabular}{|c|c|c|c|}
\hline Host & Species of Hymenolepis & Geographic locality & References \\
\hline \multirow{2}{*}{$\begin{array}{l}\text { Thomomys bottae (Ey- } \\
\text { doux and Gervais) }\end{array}$} & H. citelli (McLeod, 1933) & California & Voge, 1955 \\
\hline & Hymenolepis sp. (Weinland, 1858) & California & Voge, 1955 \\
\hline $\begin{array}{l}\text { Thomomys bulbivorus } \\
\text { (Richardson) }\end{array}$ & H. tualatinensis Gardner, 1985 & $\begin{array}{l}\text { Willamette Valley, } \\
\text { Oregon }\end{array}$ & Gardner, 1985 \\
\hline \multirow[t]{2}{*}{$\begin{array}{l}\text { Thomomys talpoides } \\
\text { (Richardson) }\end{array}$} & H. diminuta (Rudolphi, 1819) & $\begin{array}{l}\text { Eastern Washington } \\
\text { State }\end{array}$ & Rankin, 1945 \\
\hline & H. citelli & Utah & Frandsen and Grundmann, 1961 \\
\hline $\begin{array}{l}\text { Thomomys umbrinus } \\
\text { (Richardson) }\end{array}$ & H. citelli & Utah & Frandsen and Grundmann, 1961 \\
\hline \multirow{5}{*}{$\begin{array}{l}\text { Geomys bursarius } \\
\text { (Shaw) }\end{array}$} & H. diminuta & Oklahoma & Burnham, 1953 \\
\hline & $\begin{array}{l}\text { H. weldensis Gardner and Schmidt, } \\
1988\end{array}$ & Eastern Colorado & Gardner and Schmidt, 1988 \\
\hline & $\begin{array}{l}\text { H. geomydis Gardner and Schmidt, } \\
1988\end{array}$ & Eastern Colorado & Gardner and Schmidt, 1988 \\
\hline & H. weldensis & Illinois/Indiana & Haukisalmi et al., 2010 \\
\hline & Hymenolepis sp. & Texas & English, 1932 \\
\hline $\begin{array}{l}\text { Geomys lutescens Mer- } \\
\text { riam }\end{array}$ & H. weldensis & Nebraska & This study \\
\hline Geomys spp. & Hymenolepis spp. & $\begin{array}{l}\text { Midwestern United } \\
\text { States }\end{array}$ & Douthitt, 1915 \\
\hline $\begin{array}{l}\text { Cratogeomys planiceps } \\
\text { (Merriam) }\end{array}$ & H. cratogeomyos n. sp. & Toluca, Mexico & This study \\
\hline
\end{tabular}

Species of the family Hymenolepididae Perrier, 1897 have a cosmopolitan distribution, sometimes occurring in high prevalence and relatively great numerical densities in the gastrointestinal tracts of birds and mammals (Gardner et al. 2014; Makarikov et al. 2015). Spasskii (1954) was the first author to exclude the hymenolepidids with armed scolexes from the rest of the members of the family that have no armed rostellum. However, the complete life-histories of most species in the family are, as yet, unknown, but of those for which we have data, evidence shows that most life-cycles of cestodes in the Hymenolepididae are complex, and depending on the species, include a bird or 
mammal as the definitive or final-host, and some species of arthropod as the secondary or intermediate host (Gardner \& Schmidt 1988).

This paper reports two new species of cestodes that can be allocated to the family Hymenolepididae. Both were discovered during focussed surveys of pocket gophers in Mexico and Costa Rica. These new species may seem insignificant in the scheme of modern humanity, but the knowledge of their existence in rodents at a specific place and time provides a snapshot view of the ecological complexity that occurred there at that specific moment in time thus providing details about the local environment that would otherwise remain hidden (Manter, 1966; Brooks \& McLennan, 1993; Gardner \& Campbell, 1992). Subsequent work defining the phylogenetic relationships among these species will be important to enable us to understand the origin of these species relative to their host mammals; this information is essential to both implement and conduct studies based on the DAMA protocol (Brooks et al., 2014) which we fully support.

\section{Materials and methods}

Specimens used in the following description of a new genus and species of hymenolepidid were collected in 1990 from agricultural fields and pasture-land at the northeastern edge of the village/city of Potrero Cerrado in the province of Cartago in Costa Rica, elevation 2,140 m (Bonino \& Hilje, 1992). While pocket gophers identified as Heterogeomys heterodus (Peters, 1865) were collected and examined for cestodes, no information is available relative to other parasites that may have occurred in or on these same gophers. All cestodes recovered were preserved and stored in 70\% ethanol and sent to SLG by Robert M. Timm, University of Kansas. Specimens of H. heterodus collected during the survey were not deposited in a museum in Costa Rica nor anywhere else that we could find (R.M. Timm, pers comm, 1/11/2020).

Material used for the description of the new species of Hymenolepis from Cratogeomys planiceps (Merriam 1895) was collected in 1998 during field surveys led by Mark S. Hafner, Curator Emeritus, Museum of Natural Sciences, Louisiana State University, Baton Rouge, LA. Individuals of C. planiceps were collected from an area consisting of agricultural fields and mixed pine forest near the Parque Nacional Nevado de Toluca, México (Hafner et al. 2004). During this work, one individual of C. planiceps was fortuitously discovered to harbor several tapeworms. The cestodes were preserved directly in $95 \%$ ethanol without pre-processing and sent to SLG. The individual pocket gopher from which the cestodes were recovered was deposited in the mammal collection of the LSU museum of Natural Sciences (LSUMZ36120).

In the laboratory, specimens were stained with Semichon's acetic carmine, dehydrated in ethanol, cleared in terpineol and xylene, and mounted permanently on slides in Canada balsam. Specimens were studied using a Zeiss Axiophot ${ }^{\mathrm{TM}}$ microscope using both bright-field and Normarsky illumination. Images were prepared using software from Zeiss [AxioVision $\left.{ }^{\mathrm{TM}}(\mathrm{V} 4.6 .3 .0)\right]$ and Photoshop CS5 ${ }^{\mathrm{TM}}$. Line drawings were prepared directly from images using "layers" in Adobe Photoshop and a Wacom-Intuos ${ }^{\mathrm{TM}}$ tablet and stylus.

Terminology for morphological characters of adults and larval cestodes (eggs) follows Chervy (2009), Maggenti (2005), and Gardner \& Schmidt (1988). All specimens of cestodes were deposited as voucher and type specimens in the H.W. Manter Laboratory of Parasitology Parasite Collections (HWML).

Multivariate canonical discriminant (CANDISC), stepwise discriminant (STEP), and principal component analyses (PCA) were conducted with SAS ${ }^{\circledR}$ software, version 9.4 using 17 quantitative characters taken from six different species of Hymenolepis spp. and Hobergia irazuensis n. gen., n. sp. (Tables 1 \& 2). Measurement data from original archival computer files maintained by the Manter Laboratory, for the species H. diminuta (Rudolphi, 1819), H. geomydis Gardner \& Schmidt, 1988, H. weldensis Gardner \& Schmidt, 1988, H. tualatinensis Gardner, 1985, H. weldensis Gardner \& Schmidt, 1988, and H. robertrauschi Gardner et al., 2014 were taken from data originally archived in the HWML from the combined data set of Gardner at al. (2014). All measurements of cestodes collected from the pocket gophers $C$. planiceps and H. heterodus were taken from individual specimens deposited in the Manter Laboratory (HWML No. 139035-139054). An a-priori level of significance of $\mathrm{p}<0.05$ was set for all statistical analyses. Any deviations from normality in the mensural data were estimated via calculations of skewness and kurtosis using SAS and Microsoft Excel ${ }^{\mathrm{TM}}$. Variables with distributions not conforming to statistical 


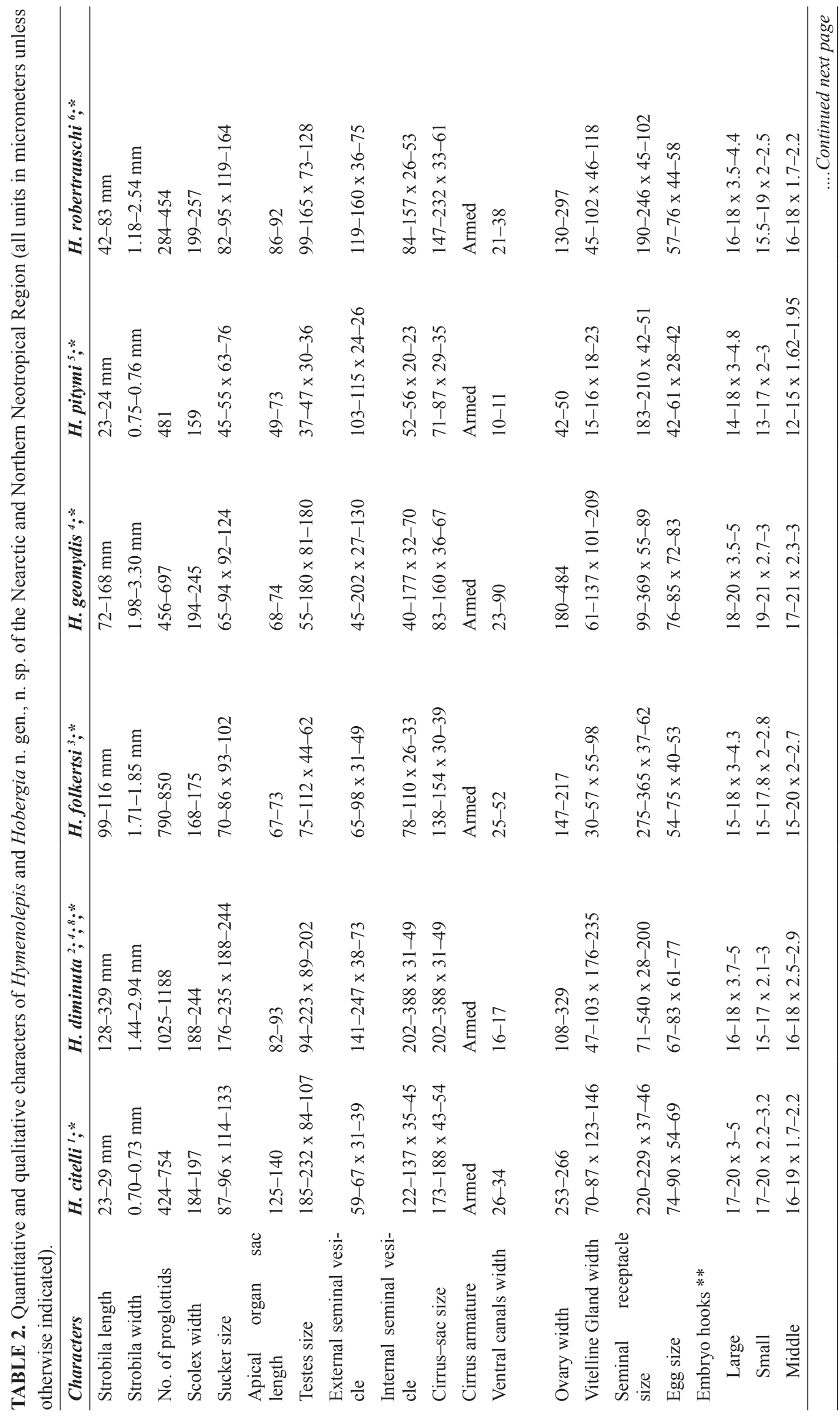




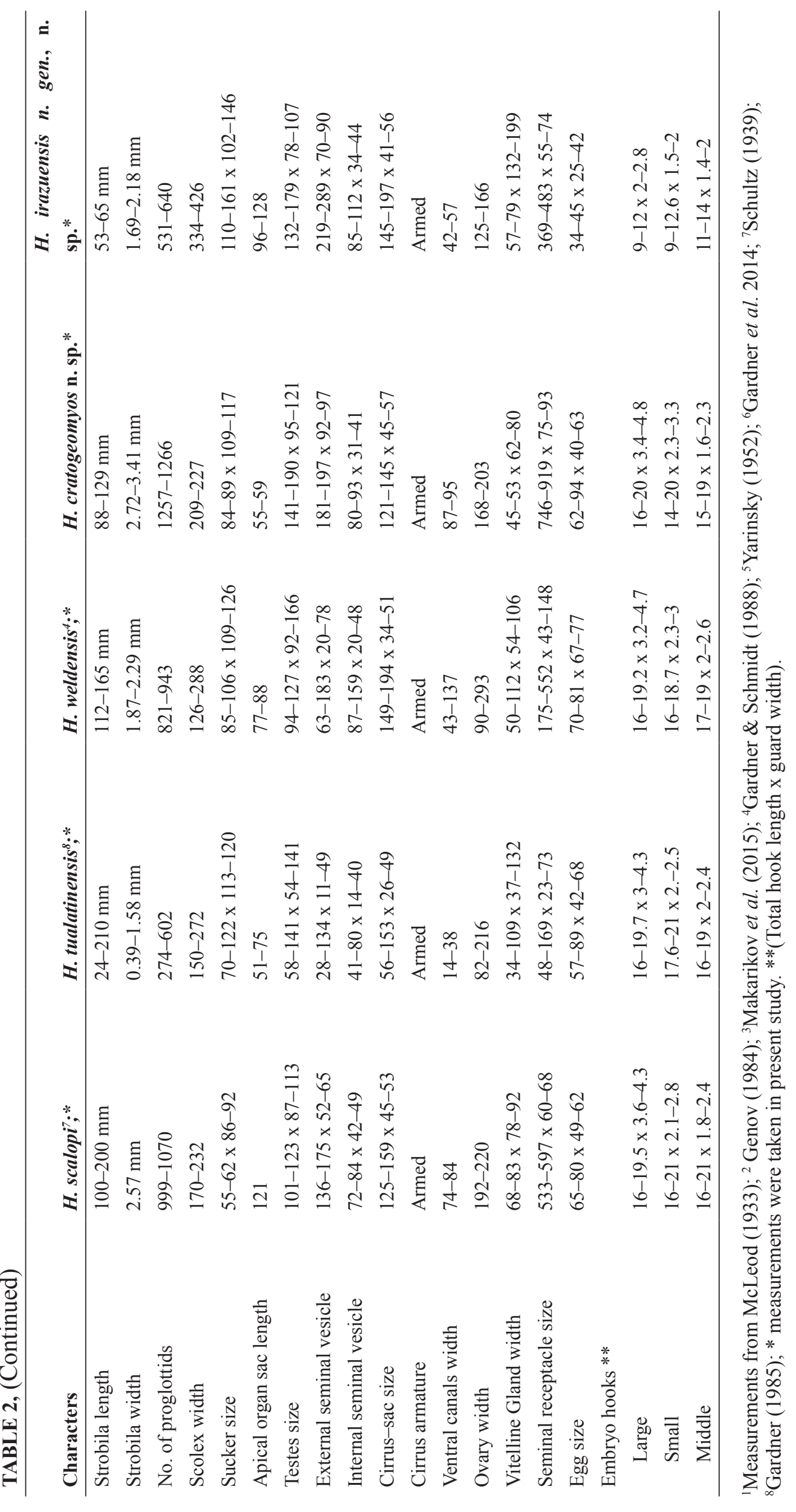


normality were $\log$ transformed $\left(\log _{10}\right)$ and reassessed for normality; any characters that deviated from normality after transformation were not used in the analyses. Log-transformed data were used for all subsequent analyses.

In the following, six species of both Hymenolepis and Hobergia $\mathbf{n}$. gen. from Rodentia were included in a canonical variates analysis using 17 quantitative-mensural characters from 41 individual cestodes (see: Table 3 and Figs. $10 \& 11$ ). To examine the data-set for well-defined groups the data were first analyzed with a PCA and subsequently analyzed using CANDISC. Five of the six Hymenolepis species analyzed are found exclusively in the Americas; however, H. diminuta as it is currently understood as a species, is cosmopolitan with a global distribution, probably made so via synanthropic hosts which are usually species of the genus Rattus Fischer 1803, but many other species of mammals have been reported as definitive or final hosts for this tapeworm (Burt, 1980). A phylogenetic analysis was conducted using a complex suite of morphological characters, the results of which are being published elsewhere (Gardner \& Racz, in review).

TABLE 3. List of characters with loadings on canonical axes and variation in canonical structure. CAN I, with more than $50 \%$ of the variation shown in the analysis is influenced most by the seminal receptacle length and external seminal vesicle length and width; CAN II which contributes about $25 \%$ to the total variation in the analysis shows number of proglottids and length of strobila to be most important in separating species.

\begin{tabular}{lllll}
\hline Variable & CAN I & CAN II & CAN III & CAN IV \\
\hline Maximum strobila length & -0.15 & -0.56 & -0.26 & 0.60 \\
Maximum strobila width & 0.33 & -0.01 & 0.06 & 0.70 \\
Number of proglottids & 0.42 & -0.68 & -0.24 & 0.50 \\
Cirrus sac length & 0.39 & 0.38 & -0.61 & 0.41 \\
Cirrus sac width & 0.44 & 0.12 & 0.45 & 0.15 \\
Internal seminal vesicle length & 0.39 & 0.27 & -0.66 & 0.38 \\
Internal seminal vesicle width & 0.12 & 0.32 & 0.32 & 0.30 \\
External seminal vesicle length & 0.68 & 0.39 & -0.07 & 0.33 \\
External seminal vesicle width & 0.69 & 0.23 & -0.02 & 0.39 \\
Testes length & 0.51 & 0.10 & -0.13 & 0.33 \\
Testes width & 0.07 & -0.13 & -0.14 & 0.65 \\
Seminal receptacle length & 0.82 & -0.04 & -0.09 & 0.21 \\
Seminal receptacle width & 0.25 & 0.02 & -0.25 & 0.49 \\
Ovary length & 0.35 & -0.40 & 0.25 & 0.00 \\
Ovary width & 0.36 & 0.31 & 0.33 & 0.70 \\
Vitelline gland width & 0.33 & 0.20 & 0.60 & 0.36 \\
Vitelline gland length & 0.02 & 0.08 & 0.09 & 0.66 \\
Percentage of variation of each canonical axis (CI) & $51.04 \%$ & $25.10 \%$ & $12.66 \%$ & $7.59 \%$ \\
Summed variation accounted for by each CI & $51.04 \%$ & $76.15 \%$ & $88.81 \%$ & $96.40 \%$ \\
\hline
\end{tabular}

\section{Results}

For the following descriptions, all measurements are given in micrometers unless otherwise specified. Character number 3 refers to number of proglottids. Number of individuals examined is indicated by $(\mathrm{N})$ and numbers in parentheses are mean \pm standard deviation (Tables $1 \& 2$ ). From complete strobilae, measurements of organs from mature regions were taken from each of the 5 proglottids immediately anterior to those proglottids in which eggs begin to appear in the uterus. 
Class Cestoda van Beneden, 1849

Order Cyclophyllidea van Beneden, 1850

Family Hymenolepididae Perrier, 1897

Subfamily Hymenolepidinae Perrier, 1896

Hobergia n. gen.

(Figs. 1-6)

LSIDurn:Isid:zoobank.org:act:439BC5C8-B0AE-4108-94ED-044B34E1DB9D

Type and only species: Hobergia irazuensis n. gen., n. sp.

Diagnosis: Hymenolepididae, Hymenolepidinae. Strobila elongate, widest at level just anterior to terminal gravid proglottids. Strobila attenuated and narrowest in neck region, posteriad to scolex. Scolex with four fully developed and separate suckers (Fig. 1). Each sucker with foveola and associated structures. Foveolae completely contain suckers when suckers are retracted (Fig. 2). Apical organ, piriform (Fig. 1). Anterior most part of osmoregulatory canals not penetrating apical organ sac. Transverse tubes connect ventral osmoregulatory canals. Genital ducts pass dorsal to osmoregulatory canals. Genital pores dextral, marginal, and unilateral. Cirrus sac, internal seminal vesicle, and external seminal vesicle dorsal to seminal receptacle, ovary, vitelline gland, and Mehlis' gland. Vitelline and Mehlis' glands posterior and slightly ventral to divided ovary. Two laterally extended lobes of ovary, connected by narrow isthmus, clearly lie on each side of vitelline gland. Gravid proglottids with transverse saccular uterus. Terminology of egg morphology follows Ubelaker (1980). Eggs (Fig. 6) subspherical, embryophore larvae with three pairs of hooks, including: $1^{\text {st }}$ pair dimorphic consisting of 1 small and 1 large hook, $2^{\text {nd }}$ (middle pair) monomorphic delicate, $3^{\text {rd }}$ pair dimorphic consisting of 1 small and 1 large hook. Large embryo hooks have a wide and thick guard compared to the small embryo hooks of both the middle pair and the paired small-hooks of $1^{\text {st }}$ and $3^{\text {rd }}$ pairs. Middle pair of embryo hooks identical, with falcate blade having shallow curve and with most delicate and narrow guard of all three embryo hook types (Fig. 6).

Etymology: The new genus is named in honor of Dr. Eric P. Hoberg who was the last curator of the United States National Parasite Collection. We honor Eric's life-long dedication and acknowledge his tireless studies of the taxonomy, systematics, phylogenetics, historical ecology, and biodiversity of parasites of planet earth.

Remarks: Definition of a new structure in the Cestoda. Scolex with pockets or depressions $=$ foveolae (see definition in Maggenti et al., 2009) into which suckers can be retracted. This structure has also been observed in tapeworms of the genus Linstowia Zschokke, 1899 (Cestoda: Anoplocephalidae) from marsupials and monotremes (Gardner \& Campbell, 1992a, b).

Hobergia irazuensis n. gen., n. sp.

(Figures 1-6)

LSIDurn:1sid:zoobank.org:act:84C2C2D1-5ACC-4177-9EC4-BE630DC7FB8

Type Host: Heterogeomys heterodus (Peters, 1865).

Type locality: Agricultural field, approximately $12 \mathrm{~km}$ from Irazú volcano, on the northeastern edge of Potrero

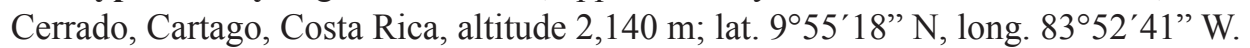

Symbiotype host: (See Frey et al., 1992) Variable pocket gopher, Heterogeomys heterodus (Peters 1865) (Rodentia: Geomyidae).

Symbiotype catalog number: Not available.

Type locality/collection date: Potrero Cerrado, Cartago, Costa Rica, Elevation: 2,140 m; lat. 9 $55^{\prime} 18^{\prime \prime} \mathrm{N}$, long. 8352'41" W; 28 March 1990.

Collector: Dr. Never Bonino and students.

Site of infection: Small intestine.

Prevalence: (5.3\%) 2 of 38 specimens of Heterogeomys heterodus infected, one male and one female.

Specimens deposited: Holotype, HWML139040

Specimens examined: Paratypes: HWML39041, HWML139042, HWML139043, HWML139044, HWML139045, HWML13946, HWML13947, HWML13948, HWML13949, HWML13950, HWML13951, HWML13952, HWML13953, HWML139054. 

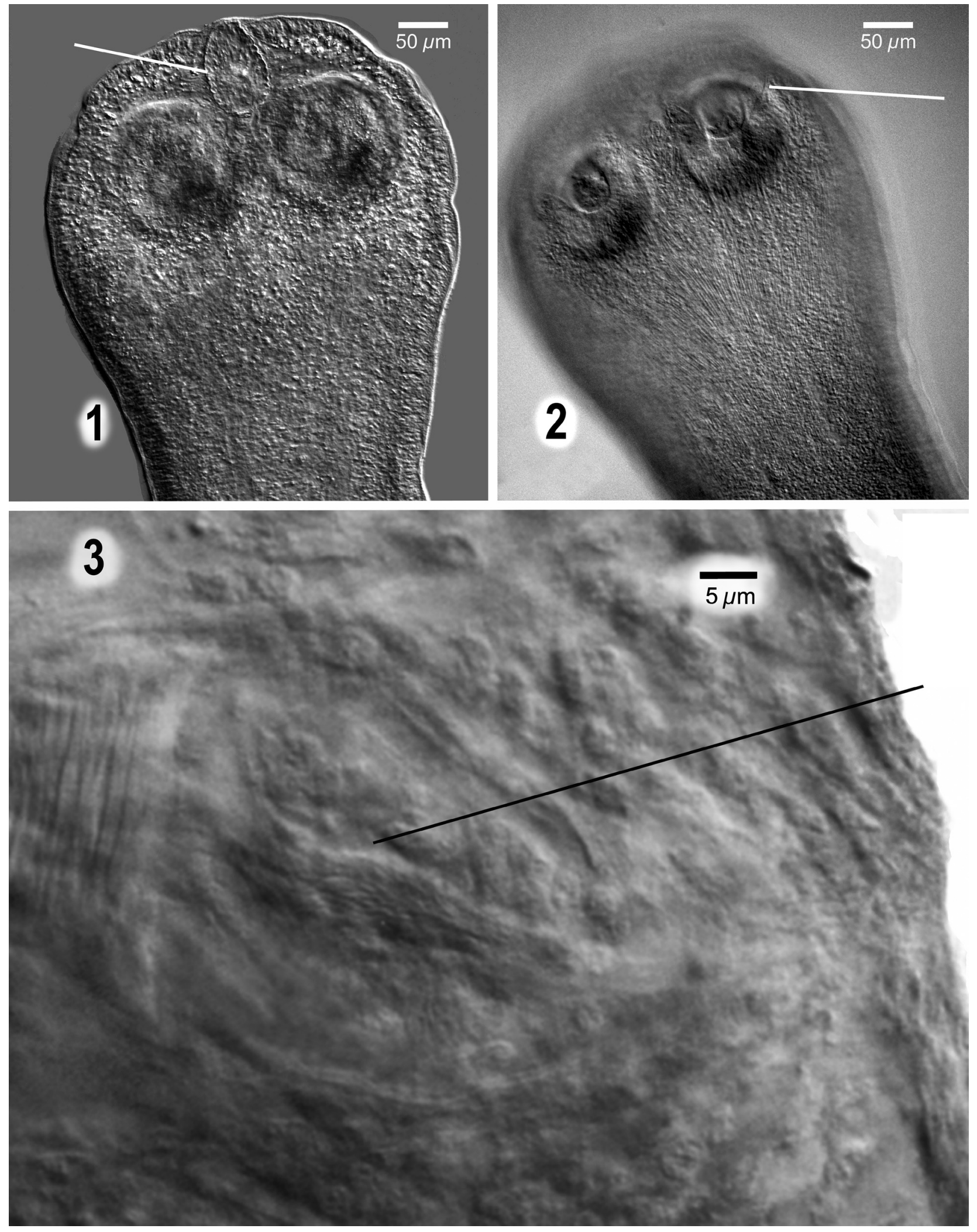

FIGURE 1. Scolex of Hobergia irazuensis n. gen., n. sp. showing details of apical organ and apical organ sac. Line indicates apical organ sac.

FIGURE 2. Scolex of Hobergia irazuensis n. gen., n. sp. showing detail of membranes on the scolex that cover the suckers creating a foveola or pocket into which each sucker can be retracted. Line indicates pocket opening.

FIGURE 3. Image of distal end of cirrus sac of Hobergia irazuensis n. gen., n. sp. showing the spinose nature of the cirrus (line). 


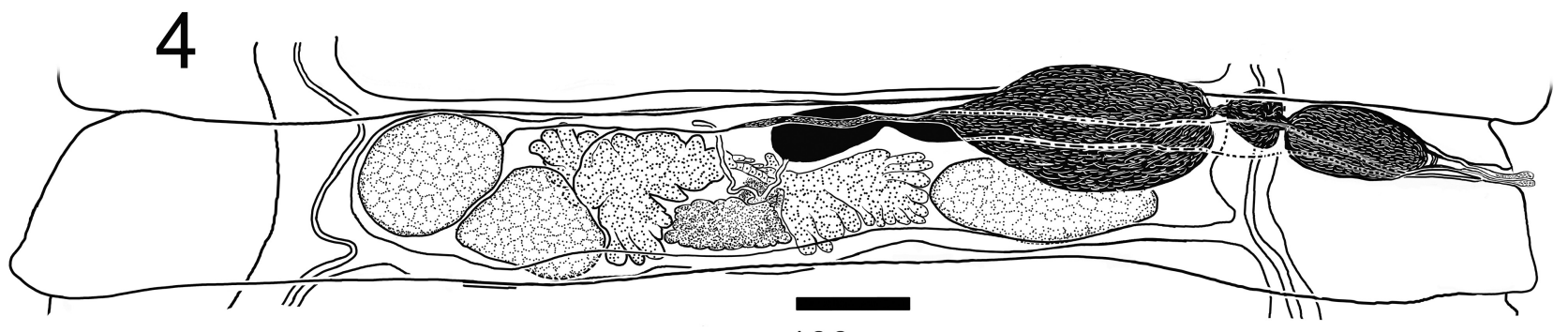

$100 \mu \mathrm{m}$

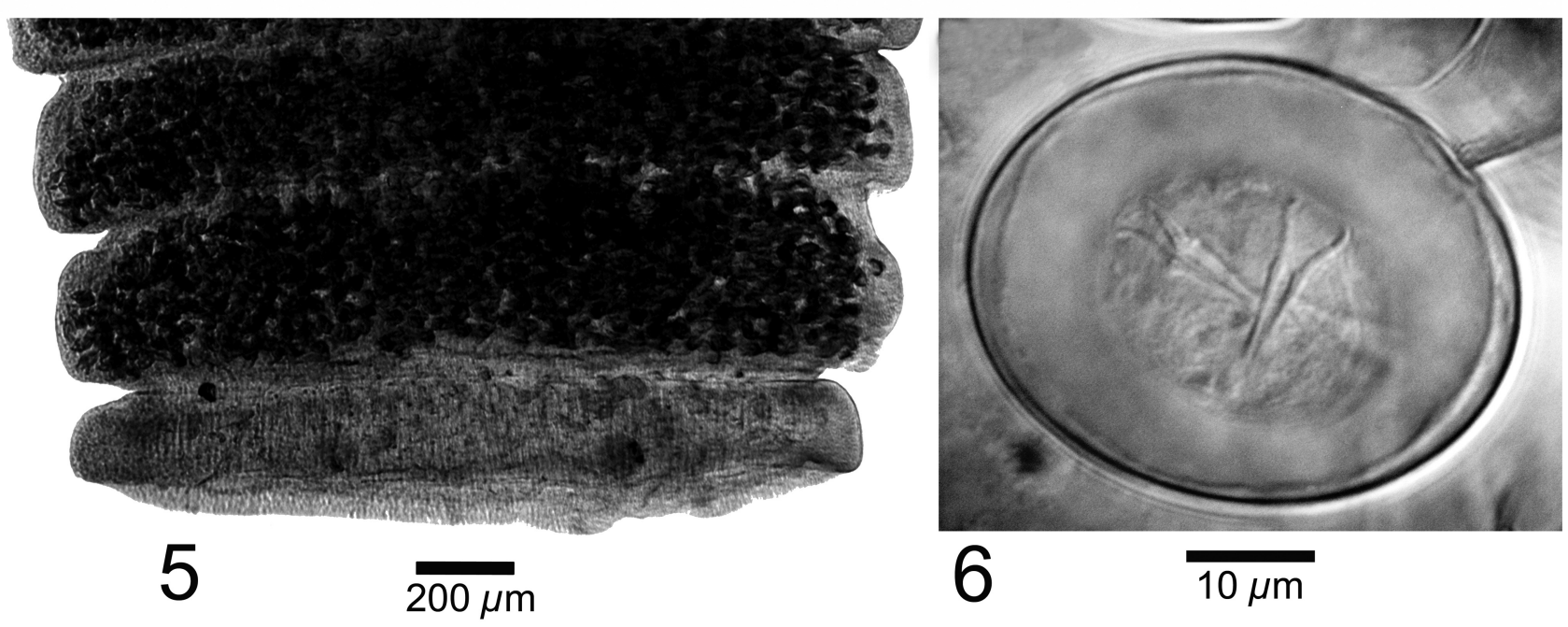

FIGURE 4. Line drawing of last mature proglottid of Hobergia irazuensis n. gen., n. sp.

FIGURE 5. Image of terminal gravid proglottids of Hobergia irazuensis n. gen., n. sp. showing the uterus filled completely with eggs in the subterminal proglottid and the terminal segment with no eggs evident (anapolytic).

FIGURE 6. Egg of H. irazuensis n. gen., n. sp. showing extent of development of embryo hooks with usual dimorphic hooks of the lateral pairs and the monomorphic hooks of the central pair in the embryophore larva.

Description: Fourteen specimens were studied for the following description, not all specimens had all characters visible. Scolex unarmed (Fig. 1), N = 5, 334-426 (393 \pm 30$)$ in maximum width. Apical organ (AO) present, $\mathrm{N}=13,20-32(24 \pm 3)$ in length. Each osmoregulatory duct terminates in the scolex near posterior end of AO but none penetrate the $\mathrm{AO}$ sac (posterior part of the $\mathrm{AO}$ ) [Figure 1]. Apical organ sac, $\mathrm{N}=12,96-128(114 \pm 9)$ long by $\mathrm{N}=9,61-75(68 \pm 5)$ wide. Apical organ sac not reaching beyond the posterior margins of suckers. Suckers, $\mathrm{N}=48$, 102-146 (128 \pm 11$)$ long by $\mathrm{N}=53,110-161(134 \pm 11)$ wide. Well-defined foveolae present (Figure 2$)$. Neck, $\mathrm{N}=$ $8,708-899(801 \pm 66)$ long by $\mathrm{N}=12,261-307(284 \pm 17)$ in maximum width. Strobila, $\mathrm{N}=4,52.85 \mathrm{~mm}-64.64 \mathrm{~mm}$ $(60.00 \pm 5.13 \mathrm{~mm})$ long, with $\mathrm{N}=8,531-640(587 \pm 34)$ proglottids; maximum width $\mathrm{N}=7,1.69-2.18 \mathrm{~mm}(1.91$ $\pm 0.19 \mathrm{~mm}$ ) occurs in gravid proglottids immediately anterior to terminal proglottids. Strobilar margins craspedote with intersegmental divisions clearly evident in mature and gravid proglottids; length-width ratio of mature and gravid proglottids $0.09-0.12(\mathrm{~N}=17)$ and $0.15-0.19(\mathrm{~N}=13)$. Proglottids wider than long. Genital pores unilateral, dextral, non-alternating. Genital atrium depth, $\mathrm{N}=7,14-18(16 \pm 2)$. Vaginal opening posterior and slightly ventral to cirrus opening. Genital ducts pass dorsally to longitudinal excretory canals. Dorsal canals, $\mathrm{N}=15,5-7(6 \pm 1)$ wide. Ventral canals, $\mathrm{N}=20,42-57(51 \pm 5)$ wide. Anlagen of genitalia first appearing $\mathrm{N}=2,828-852(840 \pm 17)$ from anterior end. Cirrus sac piriform, $\mathrm{N}=22,145-197(165 \pm 16)$ in maximum length by $\mathrm{N}=21,41-56(47 \pm 5)$ in maximum width, antiporal end not overlapping excretory canals. Cirrus claviform, armed with minute spines, $\mathrm{N}$ $=11,1.1-1.5(1.2 \pm 0.1)$ in length. Cirrus armature patterned in well-defined gridded rows (Fig. 3). Internal seminal vesicle piriform, $\mathrm{N}=12,85-111(98 \pm 9)$ long by $\mathrm{N}=14,34-44(38 \pm 4)$ wide. External seminal vesicle (ESV), $\mathrm{N}=24,220-289(251 \pm 23)$ long by $\mathrm{N}=15,70-90(80 \pm 5)$ in maximum width. ESV, elongate, fusiform, situated anterior to poral testis. Testes $\mathrm{N}=58,132-179(155 \pm 15)$ long by $\mathrm{N}=36,78-107(91 \pm 9)$ wide, one poral and two antiporal. Testes arrangement usually triangular, sometimes more linear, arrangement depends on level of contrac- 
tion (or relaxation) of strobila (relaxed strobila always with testes arranged in triangular pattern (Fig. 4). Seminal receptacle, $\mathrm{N}=12,369-482(419 \pm 41)$ long by $\mathrm{N}=18,55-74(64 \pm 6)$ in maximum width, extending anterior to ovary. Ovary $\mathrm{N}=19,125-166(148 \pm 15)$ in maximum length by $\mathrm{N}=45,288-405(341 \pm 32)$ in maximum width. Ovary markedly bilobed, each lobe subdivided into globular fan-shaped lobules extending laterad. Lateral lobes connected centrally in segment via thin isthmus (Fig. 4). Vitelline gland, $\mathrm{N}=42,132-199(172 \pm 17)$ wide by $\mathrm{N}=$ $31,57-79(67 \pm 6)$ in maximum length, margins with small lobules, situated medially and posterior to ovary and anterior to transverse ducts of ventral osmoregulatory canals. Uterus first appearing as undefined tube extending bilaterad from area of oötype, appearing quickly in developing mature proglottids with uterus extending transversely through segment before eggs are evident within. Gravid proglottids filled entirely by saccular uterus. Internal organs, displaced by gravid uterus, persist in gravid proglottids (Fig. 5). Strobila with anapolytic proglottids. Eggs $\mathrm{N}=$ 51, 34-45 (39 \pm 3$)$ long by $\mathrm{N}=51,25-42(34 \pm 3)$ wide, sub-spherical. Embryo, $\mathrm{N}=51,20-28(24 \pm 2)$ long by $\mathrm{N}=$ 51, 18-27 (21 \pm 2$)$ wide (Fig. 6), with sub-spherical shape. Embryo hooks as follows: larger hooks of first and third pairs, total length, $\mathrm{N}=51,9-12(11 \pm 1)$ long by $\mathrm{N}=51,2-3(2 \pm 0.2)$ wide at guard. Handle, $\mathrm{N}=51,4-7(6 \pm 1)$ long, blade, $\mathrm{N}=51,3-5(4 \pm 0.3)$ long. Larger hooks of first and third pairs have robust, wide guards. Smaller hooks of first and third pairs, total length, $\mathrm{N}=45,9-13(11 \pm 1)$ long by $\mathrm{N}=46,1-2(1.8 \pm 0.2)$ wide at guard. Handle, $\mathrm{N}$ $=46,4-7(6 \pm 1)$ long, blade, $N=46,3-5(4 \pm 0.4)$ long. Smaller hooks of first and third pairs have narrow, more delicate guards. Middle pair of hooks, total length, $\mathrm{N}=24,11-14(12 \pm 1)$ long by $\mathrm{N}=24,1-2(1.7 \pm 0.2)$ wide at guard, handle, $\mathrm{N}=24,6-8(7 \pm 1)$ long, blade, $\mathrm{N}=24,4-6(5 \pm 1)$ long. Middle pair of hooks usually longer than hooks of 1 st and 3rd pairs with a less tapered guard and deeply rounded blade.

Etymology: Hobergia irazuensis n. sp. was named for the Volcán Irazú near the type locality, Costa Rica, northern Neotropical region.

Remarks: Hobergia irazuensis n. gen., n. sp. exhibits the characteristics of Hymenolepis as defined by Schmidt (1986) but refined and complemented by Makarikov \& Tkach (2013). The following comparisons are restricted to members of the genus Hymenolepis known to occur in mammals of the Nearctic region, see Gardner (1985) and Gardner \& Schmidt (1988).

\section{Comparison of $\boldsymbol{H}$. irazuensis n. gen., n. sp. with other hymenolepidids found in the Nearctic}

Hobergia irazuensis n. gen., n. sp. is readily distinguishable from all other known species of Hymenolepididae in the Nearctic by the presence of sucker foveolae on the scolex. Each of the four suckers on the scolex has a pocketlike foveola in which the sucker can retract. The tissue of the foveola covers each sucker with a thin membrane (Fig. 2) which appears striated and likely involved in foveola structure or function in retraction of the suckers into the foveolae. Additionally, H. irazuensis can be differentiated from species of Hymenolepis s. str. in the Nearctic by the following characters: Ovary extremely bilobed with a central thin isthmus only a few cells in diameter; no other described species of Hymenolepis s. str. has this structure. In addition, the new species has a much longer and wider scolex and wider neck relative to all described species.

\section{Hymenolepis cratogeomyos $\mathrm{n}$. sp.}

(Figs. 7-9)

LSIDurn:Isid:zoobank.org:act:BB0861E9-71F4-4618-92BB-601F156C12F0

Symbiotype host: (see Frey et al., 1992). Volcán De Toluca Pocket Gopher, Cratogeomys planiceps Merriam 1895 (Rodentia: Geomyidae).

Symbiotype catalog number: LSUMZ 36120.

Type locality/collection date. Mexico, $10 \mathrm{~km} \mathrm{~S}, 16 \mathrm{~km} \mathrm{~W}$ Toluca, 3,000 m; lat. 19 11'

52.8’N, long. 99 48’36”'W; 17 February 1998.

Collector: Mark S. Hafner.

Site of infection: Small intestine.

Prevalence: $100 \%$ of those examined; one infected of one specimen examined.

Specimens deposited: Holotype, HWML139035.

Specimens examined: Paratypes: HWML139036, HWML139037, HWML139038, HWML139039. 

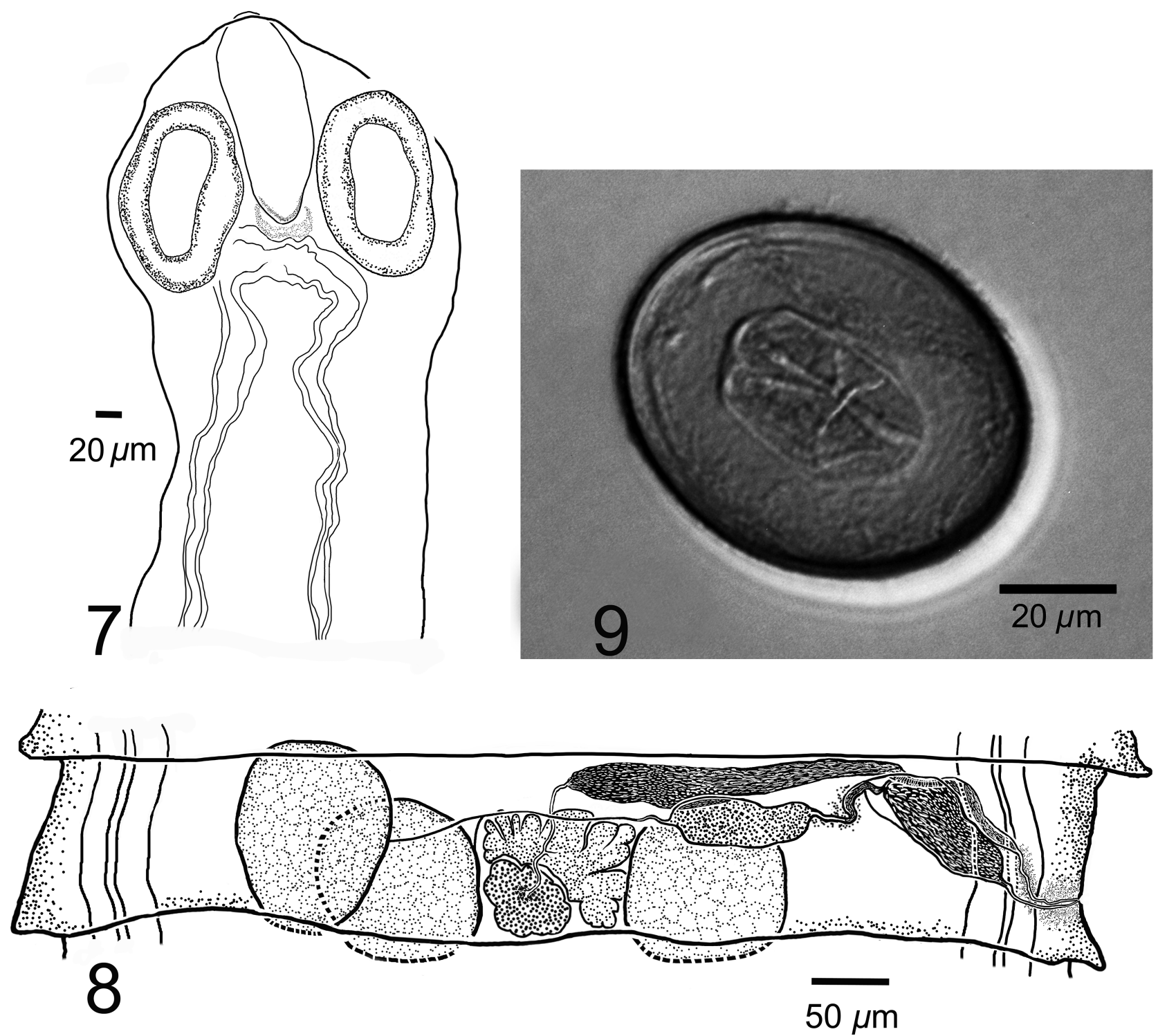

FIGURE 7. Scolex of Hymenolepis cratogeomyos n. sp. showing relatively large apical organ sac.

FIGURE 8. Line drawing of one of the last mature proglottids (see text for definition) of Hymenolepis cratogeomyos $\mathbf{n}$. sp.

FIGURE 9. Egg of Hymenolepis cratogeomyos n. sp. showing relatively delicate of development of embryo hooks with usual dimorphic hooks of the lateral pairs and the monomorphic hooks of the central pair in the embryophore larva.

Description: All specimens available were studied, including one full and 2 partial). At time of collection, specimens were placed directly into $95 \%$ ethanol, and so are extremely contracted, with only a few mature proglottids non-contracted and available to examine. Scolex (Fig. 7) unarmed, length $N=2,198-203$ (200 \pm 2.6$)$, maximum width $\mathrm{N}=2$, 209-227 (218 \pm 12.6$)$. Apical organ (AO), $\mathrm{N}=1,21.8-21.8(21.8 \pm 0)$ long. Osmoregulatory ducts terminate at base of AO, but do not appear to penetrate AO (Fig. 7). Apical organ sac, $\mathrm{N}=3,55-59(57 \pm 2)$ long by, $\mathrm{N}=2,33-37(34.8 \pm 2.9)$ wide. Apical organ sac not extending farther than posterior margins of suckers. Suckers, $\mathrm{N}=6,109-117(112 \pm 3)$ long by, $\mathrm{N}=4,84-89(87 \pm 2)$ wide. Neck, $\mathrm{N}=1,375-375(375 \pm 0)$ long by $\mathrm{N}$ $=2,169-172(170 \pm 2.3)$ in maximum width. Strobila, $\mathrm{N}=2,88.28-128.58 \mathrm{~mm}(108.42 \pm 28.49 \mathrm{~mm})$ long, with 1,257-1,266 (1,262 \pm 6) proglottids; maximum width 2.72-3.41 $\mathrm{mm}(3.06 \pm 0.49 \mathrm{~mm})$ attained in gravid proglottids. Strobila anapolytic. Strobilar margins craspedote with intersegmental divisions plainly visible in mature and gravid proglottids; length: width ratio of mature and gravid proglottids $0.09-0.178(\mathrm{~N}=4)$ and $0.11-0.177(\mathrm{~N}=4)$, respectively. Genital pores marginal, dextral, and non-alternating crossing osmoregulatory canals dorsally. Opening of genital pore ringed with deeply staining, densely packed cells. Genital atrium depth, N = 12, 20-25 (22 \pm 2$)$. Vaginal opening is anterior to cirrus opening in genital atrium. Dorsal osmoregulatory canals, $N=9,19-24$ (22 \pm 
2) wide. Ventral osmoregulatory canals, $\mathrm{N}=9,87-95(92 \pm 3)$ wide. Anlagen of genitalia $\mathrm{N}=1,119-119(119 \pm 0)$ long. Cirrus sac piriform, $\mathrm{N}=5,121-145(138 \pm 10)$ in maximum length by, $\mathrm{N}=5,45-57(52 \pm 4)$ in maximum width, the antiporal end of cirrus usually overlapping excretory canal. Cirrus clavate, armed with minute spines. Cirrus armature arranged in welldefined rows. Internal seminal vesicle piriform in shape, $\mathrm{N}=7,80-93$ (85 \pm 4$)$ long by, $\mathrm{N}=8$, 31-40 (34 \pm 3$)$ wide. External seminal vesicle, elongate fusiform, $\mathrm{N}=3,181-197(191 \pm 9)$ long by, $\mathrm{N}=$ 4, 92-97 (95 \pm 2$)$ wide. Testes ovoid, $\mathrm{N}=15,141-190(167 \pm 16)$ long by, $\mathrm{N}=19,95-121$ (106 \pm 8$)$ wide, with one poral and two antiporal. Seminal receptacle, $N=4,745-919(841 \pm 72)$ long by, $N=8,75-93$ (83 \pm 7$)$ wide, positioned anterior and dorsal to ovary and ventral to cirrus sac. Ovary, $\mathrm{N}=8,84-93(90 \pm 3)$ long by, $\mathrm{N}=12,168-203$ $(183 \pm 12)$ wide. Ovary deeply lobed, fan shaped and compacted between testes. Vitelline gland, $\mathrm{N}=8,62-80$ (72 \pm 6 ) wide by, $N=7,45-53(50 \pm 3)$ in maximum long, margins smooth. Vitelline gland near midline, anterior to intersegmental boundaries. Uterus developing laterally from origin in center of proglottid (Fig. 8). Gravid uterus saccular, overlapping osmoregulatory canals and completely filling segment and displacing all internal gonadal tissues. Eggs, $\mathrm{N}=52,62-94$ (74 \pm 6 ) long by, $\mathrm{N}=52,40-63$ (52 \pm 4 ) wide, sub-spherical. Embryophore (Fig. 9), $\mathrm{N}$ $=49,31-46(37 \pm 3)$ long by, $N=49,20-30(26 \pm 3)$ wide, sub-spherical. Embryo hooks as follows: Description of larger hooks of first and third pairs, hook length, $\mathrm{N}=60,16.0-19.9(18.0 \pm 1.0)$ by, $\mathrm{N}=60,3.4-4.8(4.1 \pm 0.4)$ wide at guard. Handle, $\mathrm{N}=60,6.8-11.0(9.3 \pm 0.9)$ long, blade, $\mathrm{N}=60,5.3-8.6(7.1 \pm 0.6)$ long. Larger hooks of first and third pairs with robust guard, thick handle, and a broad shallowly-curved, falcate, blade. Smaller hooks of first and third pairs, length, $\mathrm{N}=41,14.2-20.0(17.5 \pm 1.2)$ long $\mathrm{b}, \mathrm{N}=41,2.3-3.3(2.8 \pm 0.2)$ wide at guard; handle, $\mathrm{N}=41$, 6.9-10.9 (9.1 \pm 0.9$)$ long, blade, $N=41,5.4-8.6(7.0 \pm 0.7)$ long. Smaller hooks of first and third pairs narrow with thin guard and sub-falcate blade. Length of middle hooks, $\mathrm{N}=21,15.4-18.9(17.1 \pm 1.0)$ by, $\mathrm{N}=211.6-2.3(1.9$ $\pm 0.2)$ wide at guard; handle, $\mathrm{N}=21,7.5-10.0(9.0 \pm 0.77)$ long; blade, $\mathrm{N}=21,5.6-8.2(7.1 \pm 0.6)$ long. Guard of middle pairs of hooks reduced relative to large outer hooks, blade deeply curved and falcate (Fig. 9).

Etymology: This tapeworm species was named after the generic name of its type host "cratogeomyos" meaning "of Cratogeomys."

Differential Diagnosis: Hymenolepis cratogeomyos n. sp. exhibits characteristics of Hymenolepis as defined by Yamaguti (1959) and Schmidt (1986) but later refined by Makarikov \& Tkach (2013). There is no evidence that geomyid rodents have ever occurred in the Palearctic region (Kurtén \& Anderson, 1980) therefore we restrict comparison of this species with those of the genus Hymenolepis known to occur in mammals from the Nearctic and Neotropical regions, see Gardner (1985) and Gardner \& Schmidt (1988). Hymenolepis cratogeomyos $\mathbf{n}$. sp. can be recognized as distinct from all known species of Hymenolepis from the Nearctic region by possessing a greater width of dorsal osmoregulatory canal, longer seminal receptacle, and an apical organ sac with lightly crenulated margins.

\section{Comparisons of $H$. cratogeomyos with other hymenolepidids from geomyid rodents}

Hymenolepis cratogeomyos differs from H. geomydis in having a greater number of proglottids, longer apical organ, shorter and narrower apical organ sac, shorter neck, smaller vitelline gland, wider ventral osmoregulatory canals, longer and wider external seminal vesicle, smaller width of egg and embryo, anlagen of genitalia appearing earlier, wider guard of first and third pairs of large hooks, more compact ovary, and smooth vitelline gland margins.

Hymenolepis cratogeomyos $\mathbf{n}$. sp. can be separated from $H$. weldensis by the following characters: wider strobila, a greater number of proglottids, longer apical organ, shorter and narrower apical organ sac, shorter neck, shorter cirrus sac, longer testes, longer and wider external seminal vesicle, expanded ovary, deeper genital atrium, narrower embryo, and earlier anlagen of genitalia. Hymenolepis cratogeomyos also differs from $H$. weldensis in the shape and armature pattern of the cirrus, the cirrus of $H$. cratogeomyos is partially clavate with well-defined gridded rows of minute hooks. Hymenolepis cratogeomyos differs from $H$. tualatinensis in being larger in all respects except that H. cratogeomyos has eggs possessing embryophores that are smaller and the anlagen appears earlier in the strobila. In addition, $H$. cratogeomyos differs from $H$. tualatinensis in having an ovary that is compact, fan-shaped, and with multiple lobes, genital pores, a cirrus that is clavate and with a different pattern of spines, and eggs with hooks that are much more robust than those in $H$. tualatinensis.

Hymenolepis cratogeomyos can be readily distinguished from $H$. irazuensis by the more compact ovary (not extremely bilobed as in H. cratogeomyos) and the fact that the scolex has no sucker pockets. Hymenolepis cratogeo- 
myos can be readily distinguished from H. irazuensis in having a longer and wider strobila, greater number of proglottids, shorter and narrower apical organ sac, narrower neck, wider seminal receptacle, shorter and wider ovary, smaller vitelline gland, shorter and wider external seminal vesicle, deeper genital atrium, wider ventral excretory canal, and longer and wider eggs and embryo. The embryo hooks of $H$. cratogeomyos differ from the hooks of $H$. irazuensis by the following characters: a longer handle, blade, and total length and a narrower guard of the big and small hooks of the first and third pairs, and greater total length of the middle embryo hooks. Additionally, $H$. cratogeomyos has an ovary that is multilobed with deep small lobes and not extremely bilobed, cirrus sac that partially overlaps the ventral excretory canal, and a smooth-edged vitelline gland.

\section{Comparisons of $H$. cratogeomyos with Hymenolepis species from Sciurid, Cricetid, and Murid Rodents in the Nearctic.}

Hymenolepis cratogeomyos can be separated from $H$. robertrauschi in having a longer and wider strobila, greater number of proglottids, longer apical organ, shorter cirrus sac, longer and wider external seminal vesicle, wider ventral canals, narrower internal seminal vesicle, narrower embryo, and the anlagen of the genitalia appears earlier in the strobila. In addition, $H$. cratogeomyos differs from H. robertrauschi by the following characters: a piriform cirrus sac, cirrus armature arrangement of well-defined rows, and cirrus sac that crosses osmoregulatory canals to the mid line of the ventral canal, this in contrast to the cirrus sac of H. robertrauschi that does not touch or cross the osmoregulatory canals.

Hymenolepis cratogeomyos differs from $H$. pitymi by the following characters: longer and wider strobila, greater number of proglottids, shorter apical organ, wider apical organ sac, longer and wider neck, longer and wider cirrus sac, longer and wider external seminal vesicle, longer and wider internal seminal vesicle, wider seminal receptacle, longer and wider ovary, longer vitelline gland, deeper genital atrium, wider ventral excretory canals, longer and wider eggs, wider embryos, and greater total length of middle embryo hooks and a cirrus armature arrangement of well-defined gridded rows.

Hymenolepis cratogeomyos can be recognized as distinct from $H$. folkertsi in having a wider strobila, greater number of proglottids, shorter apical organ, shorter and narrower apical organ sac, deeper genital atrium, wider seminal receptacle, longer and wider external seminal vesicle, longer and wider testes, and wider ventral canals. Hymenolepis cratogeomyos can be distinguished from $H$. folkertsi in having the following characters: piriform cirrus sac that usually overlaps the ventral excretory canal, clavate cirrus, and a much more reduced AO relative to that of $H$. folkertsi.

Hymenolepis cratogeomyos is readily distinguishable from $H$. diminuta by the following characters: wider strobila, more great number of proglottids, longer apical organ, shorter and narrower apical organ sac, longer neck, shorter cirrus sac, wider external seminal vesicle, shorter internal seminal vesicle, deeper genital atrium, wider ventral excretory canals, narrower embryo, narrower guard of middle embryo hooks, and earlier anlagen of genitalia. Hymenolepis cratogeomyos can be recognized as distinct from $H$. diminuta by the following characters: non-alternating genital pores, a cirrus sac that usually overlaps the ventral excretory canal, and cirrus spines formed in evenly spaced rows and columns.

Generally, the characters that serve to distinguish $H$. diminuta from other species also suffice to distinguish $H$. citelli from other species as the adult characters of $H$. diminuta and $H$. citelli appear indistinguishable (Gardner \& Schmidt 1988). Hymenolepis cratogeomyos can be recognized as distinct from H. citelli by the following characters: wider strobila, shorter apical organ, shorter and narrower apical organ sac, longer and wider neck, longer and wider internal seminal vesicle, longer external seminal vesicle, longer testes, wider seminal receptacle, wider ventral excretory canal, wider cirrus sac, piriform cirrus sac, and a genital pore that is non-alternating. Note: It is the opinion of the authors that new specimens from the type locality of $H$. citelli should be collected to confirm its validity.

Hymenolepis cratogeomyos can be recognized as distinct from H. scalopi Schultz, 1939 described from Scalopus aquaticus Linnaeus, 1758 collected from the vicinity of Stillwater, Oklahoma by the following characters (see Table 2): wider strobila, greater number of proglottids, longer apical organ, shorter and narrower apical organ sac, earlier anlagen of genitalia, longer and wider external seminal vesicle, longer testes, wider seminal receptacle, shorter ovary, shorter vitelline gland, wider and shorter neck, deeper genital atrium, and a larger ventral excretory canal. In addition, H. cratogeomyos can be separated from H. scalopi in having a piriform cirrus sac that extends 
further than the ventral excretory canal, and a larger ovary that is expanded laterally. Note: It is interesting that this species has never been reported after its initial description. At this time we have been unable to locate the voucher specimens of the type host $H$. scalopi so it remains an enigma as to whether this cestode was actually recovered from a mole collected from near Stillwater, OK.

\section{Prevalence of hymenolepidids in Geomyidae of Costa Rica and México}

During the field work by Bonino in Costa Rica (1989-1990), 127 individuals of $H$. heterodus, were collected and examined for helminths. Hobergia irazuensis n. gen., n. sp. was found in 1.6\% of all specimens examined; all infected individual pocket gophers were found at a single collection locality, occurring in $5.3 \%$ of those individuals of $H$. heterodus examined at the locality Potrero Cerrado.

Relative to Hymenolepis cratogeomyos $\mathbf{n}$. sp., one individual of $C$. planiceps was incidentally found infected with cestodes (Hafner et al. 2004).

\section{Statistical Analyses}

To examine the extent of morphological divergence among all species of Hymenolepis s. str. in the Nearctic and Northern Neotropical regions a PCA and CANDISC were performed. The PCA ordination (Fig. 10) shows relatively good separation of species using the first two components. The CANDISC ordination (discriminant analysis works on previously defined groups and maximizes the differences among the groups) shows distinct separation among all species included in this analysis (Fig. 11). The CANDISC analysis shows that all multivariate means or centroids are significantly different from each of the seven species of hymenolepidids evaluated $(\mathrm{F}=11.34, \mathrm{df}=102,109.62, \mathrm{p}$ $<0.0001)$. Characters most important for discriminating among species in this study were determined by stepwise discriminant analysis and include: number of proglottids, cirrus sac length, maximum strobila length, ovary width, seminal receptacle length, vitelline gland width, cirrus sac width, and maximum strobila width. Measurements of scolexes, eggs, and embryophores were not included in the multivariate analysis due to the low number of these characters available for comparative species.

\section{Discussion}

The discovery of these two new species of cestodes adds critical new information to our knowledge of the known species of rodent-specific Hymenolepididae in both the Mesa Central of Mexico and the volcanic region of Costa Rica. The record of Hobergia irazuensis from H. heterodus in the highlands of Costa Rica is the first report of a hymenolepidid from geomyid rodents in the northern neotropics; however, we expect that additional sampling of geomyids throughout their ranges will reveal hidden parasite diversity that has been previously ignored by biodiversitists.

Across the Nearctic and northern Neotropical regions, six species of the genus Hymenolepis are now known to occur in species from three of the six genera of Geomyidae. Hymenolepis citelli and H. weldensis have been reported from more than one species of geomyid rodent (Gardner \& Schmidt 1988) and both H. diminuta (Table 1) and $H$. weldensis have been transferred experimentally to, and appear to thrive in, experimentally infected species of Geomys, Thomomys, and Cratogeomys (see Gardner \& Schmidt 1988). The fact that Hymenolepis weldensis and $H$. diminuta were transferred experimentally from geomyids to beetles of the family Tenebrioniidae (Tenebrio molitor L.) and then to gophers, indicates that any host specificity of these species of tapeworms to geomyids does not manifest or show physiological or phylogenetic host specificity, but instead is most likely a result of ecological host specificity (separation of host and parasite based on ecology or geographic distances). Based on the potential for ecological fitting (see reviews in Brooks et al., 2014 and Weaver et al., 2016) of Hymenolepis spp. among the diverse and widely distributed species of Geomyidae and the requirements of the complex life cycles of these cestodes combined with the broad geographic distribution of the geomyids, it is clear that additional biodiversity surveys throughout the Nearctic and Neotropical regions are required to understand the dynamic evolutionary and ecological history of the species of Hymenolepididae in geomyid rodents. 


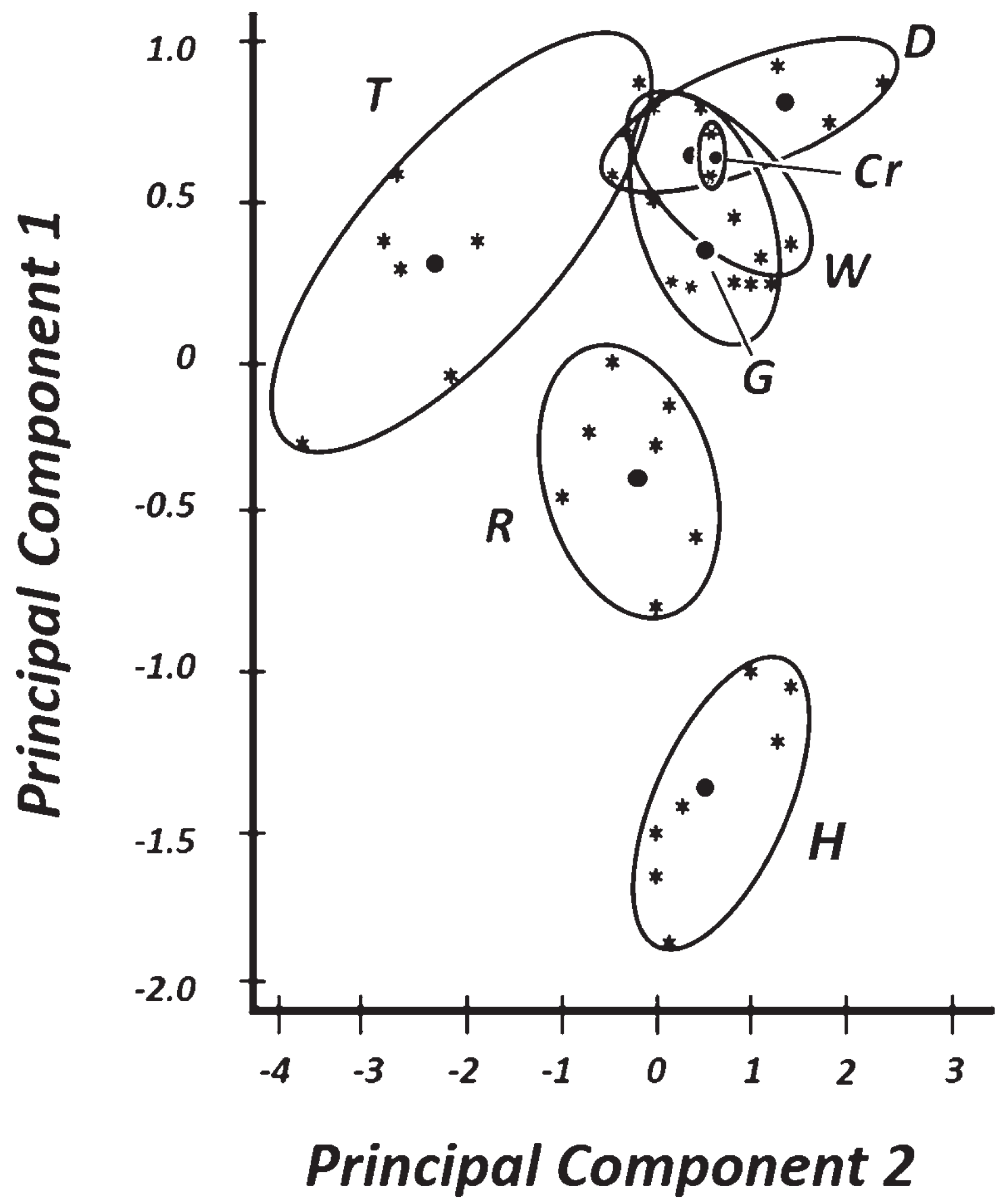

FIGURE 10. Ordination of first two principal components derived from a PCA of morphometric characters of seven species of Hymenolepididae, ellipse labels as follows: $\mathrm{H}=$ Hobergia irazuensis $\mathbf{n}$. gen., n. sp.; $\mathrm{Cr}=$ H. cratogeomyos $\mathrm{n}$. $\mathrm{sp}$.; $\mathrm{D}=H$. diminuta $; \mathrm{G}=H$. geomydis; $\mathrm{R}=H$. robertrauschi $; \mathrm{T}=H$. tualatinensis; $\mathrm{W}=H$. weldensis. 


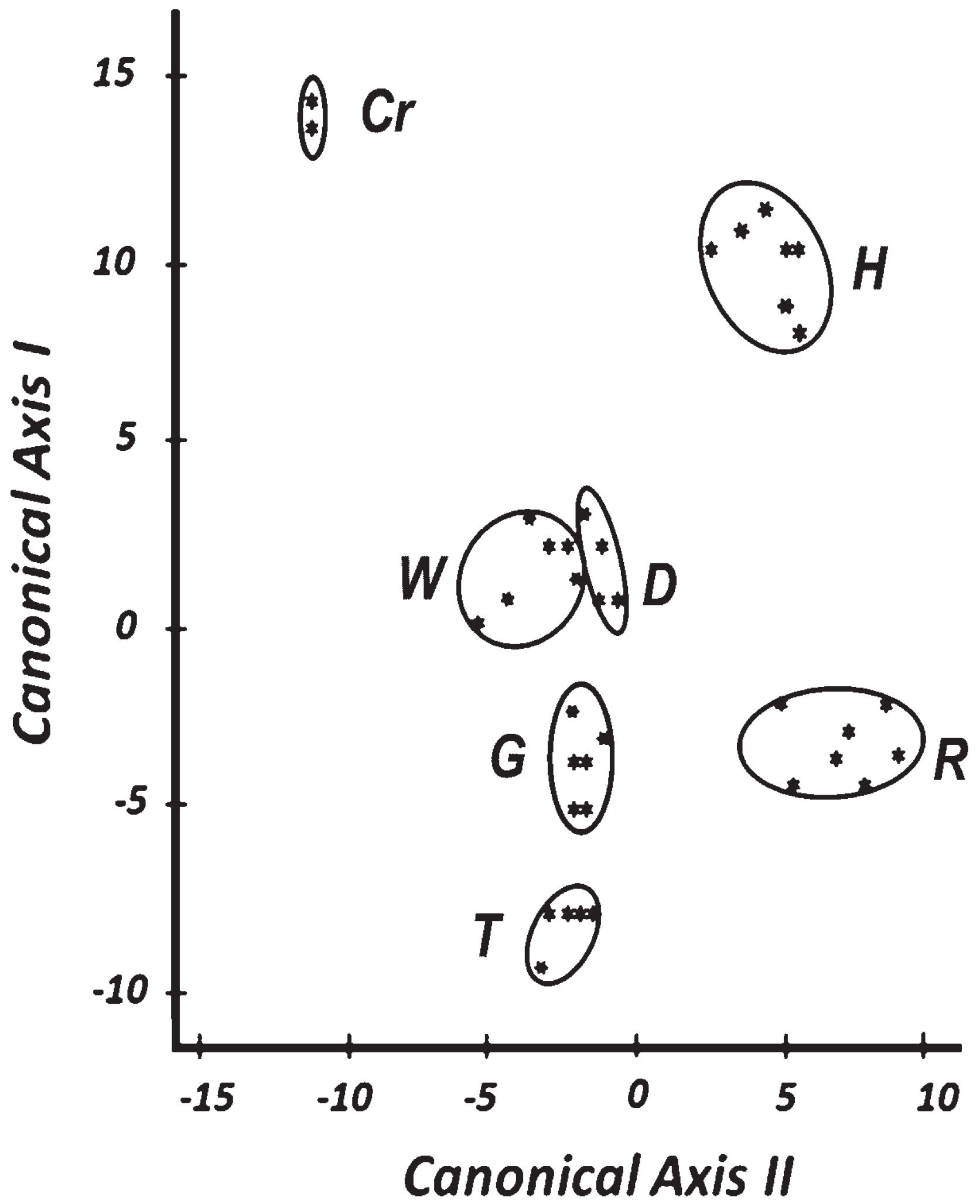

FIGURE 11. Ordination plot of the first two axes derived from a canonical discriminant morphometric analysis (CANDISC) of six species of Hymenolepis and Hobergia irazuensis $n$. gen. n. sp. Ellipse labels as follows: $\mathrm{H}=H$. irazuensis $\mathrm{n}$. sp.; Cr. $=H$. cratogeomyos $\mathrm{n}$. $\mathrm{sp}$.; $\mathrm{D}=H$. diminuta $; \mathrm{G}=H$. geomydis $; \mathrm{R}=H$. robertrauschi $; \mathrm{T}=H$. tualatinensis $; \mathrm{W}=H$. weldensis. Asterisks represent the scatter of individuals in discriminant space.

Parasites with complex life-cycles, such as cestodes that occur in species of Geomyidae, are important indicators of biodiversity that is many times hidden with only parts of the fauna of a region or locality functioning in host- 
parasite systems (Manter 1966; Brooks \& McLennan 1993). If a parasite with a complex life-cycle is shown to be present in one or several host species in an area, it is immediately clear that all essential ecological requirements for both definitive and intermediate hosts are also present in the ecosystem (Gardner \& Campbell 1992; Hoberg 1997). Thus, discovery of parasites with complex life-cycles in this case, mammals, but in fact any other vertebrates in any geographic locality serves to immediately expose to examination previously hidden and perhaps unknown and undiscovered biodiversity. Finally, putting the species associated with these discoveries into a phylogenetic context adds historical depth to the discovery of species (Gardner \& Campbell 1992; Brooks et al. 2014; Racz \& Gardner submitted).

With the inclusion of the two new hymenolepidids described herein, we consider the genus Hymenolepis to contain 20 species with one new species allocated to a new genus, defined above.

\section{Acknowledgments}

We thank the students who worked so hard to collect pocket gophers in both Costa Rica and in Mexico all those years ago. Thanks to Mark S. Hafner, Robert M. Timm, and Never Bonino for sending the specimens of cestodes to SLG and then waiting all this time to see the results. This paper is dedicated to the memory of Dr. Robert L. Rausch, for without his encouragement and guidance, SLG would never have met Eric P. Hoberg. Part of this work was funded by NSF grants to SLG including (DEB-9621395, DEB-0097019, DBI-1458139, and DBI-1756397).

\section{References}

Alberico, M. (1990) A new species of pocket gopher (Rodentia: Geomyidae) from South America and its biogeographic significance. In: Peters, G. \& Hutterer, R. (Eds.), Vertebrates in the Tropics: Proceedings of the International Symposium on Vertebrate Biogeography and Systematics in the tropics, Bonn, 5-8 June 1989. Alexander Koenig Zoological Research Institute and Zoological Museum, Bonn, pp. 103-111.

Bartel, M.H. \& Gardner, S.L. (2000) Arthropod and helminth parasites from the plains pocket gopher, Geomys bursarius bursarius from the hosts' northern boundary range in Minnesota. Journal of Parasitology, 86, 153-156. https://doi.org/10.1645/0022-3395(2000)086[0153:AAHPFT]2.0.CO;2

Bonino-Vassallo, N.A. \& Hilje-Quirós, L. (1992) Comparación de dos métodos de combate de la taltuza Orthogeomys heterodus Rodentia, Geomyidae en Costa Rica. Manejo Integrado de Plagas, 23, 39-45.

Brooks, D.R. \& McLennan, D.A. (1993) Parascript: Parasites and the language of evolution. University of Chicago Press, Chicsgo, $429 \mathrm{pp}$.

Brooks, D.R., Hoberg, E.P., Boeger, W.A., Gardner, S.L., Galbreath, K.E., Herczeg, D., Mejia-Madrid, H.H., Rácz, S.E. \& Dursahinhan, A.T. (2014) Finding them before they find us: informatics, parasites, and environments in accelerating climate change. Comparative Parasitology, 81, 155-164. https://doi.org/10.1654/4724b.1

Burnham, G.L. (1953) A study of the helminth parasites of the pocket gophers of Woods, Alfalfa, Grant, and Marshall Counties, Oklahoma. Proceedings of the Oklahoma Academy of Science, 34, 59-61.

Burt, M.D.B. (1980) Aspects of the life history and systematics of Hymenolepis diminuta. In: Arai, H.P. (Ed.), Biology of the Tapeworm Hymenolepis diminuta. Academic Press, New York, New York, pp. 1-57. https://doi.org/10.1016/B978-0-12-058980-7.50006-3

Chervy, L. (2009) Unified terminology for cestode microtriches: a proposal from the International Workshops on Cestode Systematics in 2002-2008. Folia Parasitologica, 56, 199-230. https://doi.org/10.14411/fp.2009.025

Douthitt, H. (1915) Studies on the Cestode Family: Anoplocephalidae. Illinois Biological Monograph, University of Illinois, Champaign, Illinois, 96 pp. https://doi.org/10.5962/bhl.title.16798

English, P.F. (1932) Some habits of the pocket gopher, Geomys breviceps breviceps. Journal of Mammalogy, 13, $126-132$. https://doi.org/10.2307/1374048

Frandsen, J.C. \& Grundmann, A.W. (1961) Endoparasitism in isolated populations of rodents of the Lake Bonneville Basin, Utah. Journal of Parasitology, 47, 391-396. https://doi.org/10.2307/3275360

Frey, J.K., Duszynski, D.W., Gannon, W.L., Yates, T.L. \& Gardner, S.L. (1992) Designation and curatorial management of type host specimens (symbiotypes) for new parasite species. Journal of Parasitology, 78, 930-932. https://doi.org/10.2307/3283335

Gardner, S.L. (1985) Helminth parasites of Thomomys bulbivorus (Richardson) (Rodentia: Geomyidae), with the description of 
a new species of Hymenolepis (Cestoda). Canadian Journal of Zoology, 63, 1463-1469.

https://doi.org/10.1139/z85-219

Gardner, S.L. \& Schmidt, G.D. (1988) Cestodes of the genus Hymenolepis Weinland, 1858 sensu stricto from pocket gophers Geomys and Thomomys spp. (Rodentia: Geomyidae) in Colorado and Oregon, with a discriminant analysis of four species of Hymenolepis. Canadian Journal of Zoology, 66, 896-903.

https://doi.org/10.1139/z88-132

Gardner, S.L. \& Campbell, M.L. (1992) Parasites as probes for biodiversity. Journal of Parasitology, 78, 596-600. https://doi.org/10.2307/3283534

Gardner, S.L., Luedders, B. \& Duszynski, D. (2014) Hymenolepis robertrauschi n. sp. from Grasshopper mice Onychomys spp. in New Mexico and Nebraska, U.S.A. Occasional Papers Museum of Texas Tech University, 332, 1-10.

Genov, T. (1984) Helminths of insectivores and rodents in Bulgaria. Publishing House of the Bulgarian Academy of Sciences. Sofia, Bulgaria, pp. 1-348.

Hafner, M.S., Spradling, T.A., Light, J.E., Hafner, D.J. \& Demboski, J.R. (2004) Systematic revision of pocket gophers of the Cratogeomys gymnurus species group. Journal of Mammalogy, 85, 1170-1183. https://doi.org/10.1644/ber-122.1

Hall, E.R. (1981) The mammals of North America. $2^{\text {nd }}$ Edition. Wiley and Sons, New York, pp. 1-1181. https://doi.org/10.2307/1380295

Haukisalmi, V., Hardman, L.M., Foronda, P., Feliu, C., Laakkonen, J., Niemimaa, J., Lehtonen, J.T. \& Henttonen, H. (2010) Systematic relationships of hymenolepidid cestodes of rodents and shrews inferred from sequences of 28S ribosomal RNA. Zoologica Scripta, 39, 631-641. https://doi.org/10.1111/j.1463-6409.2010.00444.x

Hennig, W. (1966) Phylogenetic Systematics. University of Illinois Press, Urbana, Illinois, 256 pp. https://doi.org/10.1002/mmnd.19820290131

Hughes, R.C. (1940) The genus Hymenolepis Weinland 1858. Technical Bulletin Oklahoma Agricultural Experiment Station, $8,1-42$.

Hoberg, E.P. (1997) Phylogeny and Historical Reconstruction: Host-Parasite Systems as Keystones in Biogeography and Ecology. In: Reaka-Kudla, M.L.,Wilson, D.E. \& Wilson, E.O. (Eds.), Biodiversity II: Understanding and Protecting Our Biological Resources. Joseph Henry Press, Washington, D.C., pp. 243-262. [551 pp.] https://doi.org/10.17226/4901

Kurtén, B. \& Anderson, E. (1980) Pleistocene Mammals of North America. Columbia University Press, New York, pp. 1-442. https://doi.org/10.2307/1380422

Maggenti, A.R. \& Maggenti, M.A. (2005) Dictionary of Invertebrate Zoology. University of Nebraska-Lincoln, Digital Commons, 976 pp. [Gardner, S.L. (Ed.)] https://doi.org/10.13014/K2DR2SN5

Makarikov, A.A., Gardner, S.L. \& Hoberg, E.P. (2012) New species of Arostrilepis (Eucestoda: Hymenolepididae) in Members of Cricetidae and Geomyidae (Rodentia) from the western Nearctic. Journal of Parasitology, 98, 617-626. https://doi.org/10.1645/ge-2943.1

Makarikov, A.A., Nims, T.N., Galbreath, K.E. \& Hoberg, E.P. (2015) Hymenolepis folkertsi n. sp. (Eucestoda: Hymenolepididae) in the oldfield mouse Peromyscus polionotus (Wagner) (Rodentia: Cricetidae: Neotominae) from the southeastern Nearctic with comments on tapeworm faunal diversity among deer mice. Parasitology Research, 114, 2107-2117. https://doi.org/10.1007/s00436-015-4399-x

Makarikov, A.A., Tkach, V.V., Villa, S.M. \& Bush, S.E. (2015) Description of two new species of Hymenolepis Weinland, 1858 (Cestoda: Hymenolepididae) from rodents on Luzon Island, Philippines. Systematic Parasitology, 90, $27-37$. https://doi.org/10.1007/s11230-014-9528-x

McLeod, J.A. (1933) A parasitological survey of the genus Citellus in Manitoba. Canadian Journal of Research, 9, $108-127$. https://doi.org/10.1139/cjr33-072

Rácz, S.E. \& Gardner, S.L. (2020) A morphological phylogeny of Hymenolepis sensu stricto and other tapeworms of the Neotropical and Nearctic regions. The Journal of Parasite Biodiversity. [in review at Manter]

Rankin, J.S. (1945) Ecology of the helminth parasites of small mammals collected from Northrup Canyon, Upper Grand Coulee, Washington. The Murrelet, 26 (1), 11-14. https://doi.org/10.2307/3536106

Russell, R.J. (1968) Evolution and classification of the pocket gophers of the subfamily Geomyinae. University of Kansas Publications, Museum of Natural History, 16, 475-579.

SAS Institute Inc. (2013) Base SAS ${ }^{\circledR}$ software version 9.4 Procedures Guide. SAS Institute Inc. Cary, North Carolina Available from: https://support.sas.com/documentation/cdl/en/procstat/66703/PDF/default/procstat .pdf (accessed 12 May 2017)

Schmidt, G.D. (1986) CRC Handbook of tapeworm identification. CRC Press, Inc., Boca Raton, Florida, pp. 1-675.

Schultz, R.L. (1939) Hymenolepis scalopi n. sp. American Midland Naturalist, 22 (3), 641-645. https://doi.org/10.2307/2420519

Simpson, G.G. (1928) Pleistocene mammals from a cave in Citrus County, Florida. American Museum Novitates, $328,1-16$.

Solari, S., Muñoz-Saba, Y., Rodríguez-Mahecha, J.V., Defler, T.R., Ramírez-Chaves, H.E. \& Trujillo, F. (2013) Riqueza, endemismo y conservación de los mamíferos de Colombia. Mastozoología Neotropical, 20, 301-365.

Spasskii. A.A. (1954) Classification of hymenolepidids of mammals. Trudy Gel'mintologcheskoy Laboratorii, 7, $120-134$. 
Spradling, T.A., Demastes, J.W., Hafner, D.J., Milbach, P.L., Cervantes, F.A. \& Hafner, M.S. (2016) Systematic revision of the pocket gopher genus Orthogeomys. Journal of Mammalogy, 97, 405-423. https://doi.org/10.1093/jmammal/gyv185

Ubelaker, J.E. \& Downhower, J.F. (1965) Parasites recovered from Geomys bursarius in Douglas County, Kansas. Transactions of the Kansas Academy of Science (1903-), 68, 206-208.

Ubelaker, J.E. (1980) Structure and ultrastructure of the larvae and metacestodes of Hymenolepis diminuta. In: Arai, H.P. (Ed.), Biology of the tapeworm Hymenolepis diminuta. Academic Press, New York, pp. 59-156. [733 pp.] https://doi.org/10.1016/B978-0-12-058980-7.50007-5

Voge, M. (1955) A list of cestode parasites from California mammals. American Midland Naturalist, 54, $413-417$. https://doi.org/10.2307/2422576

Wardle, R.A. \& McLeod, J.A. (1952) The zoology of tapeworms. University of Minnesota Press, Minneapolis, Minnesota, 780 pp. https://doi.org/10.1126/science.116.3001.22

Wilkins, K.T. (1985) Pocket gophers of the genus Thomomys Rodentia: Geomyidae from the Pleistocene of Florida USA. Proceedings of the Biological Society of Washington, 98, 761-767.

Wilson, D.E. \& Reeder, D.M. (2005) Mammal species of the world: a taxonomic and geographic reference. Johns Hopkins University Press, Baltimore, Maryland, $2142 \mathrm{pp}$.

Yamaguti, S. (1959) Systema helminthum. Vol. II. The cestodes of vertebrates. Interscience Publishers, Inc., New York and London, $860 \mathrm{pp}$.

Yarinsky, A. (1952) Hymenolepis pitymi n. sp., a hymenolepidid cestode from the pine mouse. Journal of the Tennessee Academy of Science, $27,150-152$. 